\title{
CEO Education-Performance Relationship: Evidence from Saudi Arabia
}

\author{
Basmah Maziad ALTUWAIJRI ${ }^{1}$, Lakshmi KALYANARAMAN ${ }^{2}$
}

Received: June 04, 2020 Revised: June 21, 2020 Accepted: July 09, 2020

\begin{abstract}
The study investigates the association between CEO education and firm performance with a sample of 85 nonfinancial firms listed on the Saudi stock exchange during 2018 applying ordinary least squares method. CEO education is defined by three variables, the level of education, if the degree-granting institution is domestic or foreign, and if the highest degree is in management or other fields of study. Financial performance is measured by return on assets and return on equity. Firm size, age, liquidity and growth are introduced as control variables. The study shows that $58 \mathrm{CEO}$ of the firms studied are graduates, 38 have obtained their degree from a domestic institution and 44 have a management degree. Graduate CEOs are found to enhance performance. Graduating from a domestic institution influences performance positively. Management degree of CEO does not seem to impact performance. Firm size, liquidity and growth are positively associated with performance. Firm age does not explain performance differences of firms. Results are robust to performance measures. The findings of the study suggest that firms can benefit from a CEO hiring policy that emphasizes on the minimum qualification set as graduation or higher, education from a domestic institution and no undue weight on management qualification.
\end{abstract}

Keywords: CEO Education, Firm Performance, Management Degree, Business Leadership, Saudi Arabia

JEL Classification Code: I21, L25, M12, M51, N15

\section{Introduction}

The empirical literature has well established that CEO (Chief Executive Officer) characteristics can explain the differences in firm performance (Adams, Almeida \& Ferreira, 2005; Graham, Harvey \& Puri, 2013; Kaplan, Klebanov \& Sorensen, 2012; King, Srivastav \& Williams, 2016; Malmendier, Tate and Yan, 2011). In search of answer to the question, "What characteristics of CEO can enhance firm performance?", several CEO characteristics like narcissism, leadership, team-building ability, overconfidence, integrity, efficiency, gaining stakeholders' trust, efficiency, etc.,

${ }^{1}$ First Author. Management Consultant, Basmah Altuwaiji Office for Consultancy Services, Riyadh, Saudi Arabia.

Email: basmah7@gmail.com

${ }^{2}$ Corresponding Author. Professor, Department of Finance, King Saud University, Riyadh, Saudi Arabia [Postal Address: P. O. Box 305220, Riyadh, 11361, Saudi Arabia]

Email: kaylakshmi@gmail.com

(c) Copyright: The Author(s)

This is an Open Access article distributed under the terms of the Creative Commons Attribution Non-Commercial License (http://Creativecommons.org/licenses/by-nc/4.0/) which permits unrestricted noncommercial use, distribution, and reproduction in any medium, provided the original work is properly cited. are listed (Bertrand \& Scholar, 2003; Bhagat, Bolton \& Subramanian, 2010; Colbert, Barrick \& Bradley, 2014; Hiller $\&$ Hambrick, 2005). The major challenge that empirical works face is to define a quantifiable measure that represents these attributes (Falato, Li \& Milbourn, 2015). Since education weighs heavily on the CEO recruitment and compensation, it is proposed as the objective measure of CEO's ability to impact firm performance (Bhagat et al., 2010; Graham, Li \& Qiu, 2012). This choice is justified by empirical works that proxy CEO education for technical and managerial competency (Bowers \& Seashore, 1966), ability to handle complex information and take fast decisions (Hunter, 1986), receptivity to new ideas (Thomas, Litschert \& Ramaswamy, 1991), entrepreneurial drive (Robinson \& Sexton, 1994), cognitive ability (Wally \& Baum, 1994), prestige (Certo, 2003), ability to cope with uncertain scenarios (Gottfredson, 2003), openness to innovation and adaptability to change (Ng \& Feldman, 2009), thinking process (Gottesman \& Morey, 2010), ability to devise effective strategies (Xiaowei \& Zhang, 2010), and managerial effectiveness (Saidu, 2019). However, the literature on CEO education-performance link is still evolving.

Empirical works on CEO education-performance have come up with mixed results. Some works show a positive 
association (Elsharkawy, Paterson, \& Sherif, 2018; King et al., 2016), while others show no significant relation between the two variables (Gottesman \& Morey, 2010; Jalbert, Furumo \& Jalbert, 2011). More research is needed to bring consensus on CEO education-performance link. This research contributes to the literature in at least two significant ways. One, the study attempts to provide a definitive answer to the question whether CEO education influences firm performance. Second, most of the studies that investigate CEO education-performance connection are carried out in the US (Morresi, 2017). There is a need to carry out similar studies in other countries. This study produces evidence of this link in Saudi Arabia, a country where a similar study does not exist.

\section{Literature Review and Hypothesis Development}

Several theories offer the framework for understanding the CEO education-performance link. Human capital theory (Becker, 1964; Mincer, 1958) suggests that a firm can profit from the cognitive and productivity ability of an individual derived from the individual's stock of experience, education and skills. The theory argues that the marginal productivity of labor is determined by education that has the potential to influence the firm's earnings. The theory proposes a positive CEO education-performance link. Proponents of upper echelons theory (Hambrick \& Mason, 1984) argue CEO characteristics like experience, values and personality hold the key to understanding the strategic choices of the firm and its performance. Empirical testing of the theory suggests that CEOs who are highly educated are more knowledgeable with better cognitive ability. This ability positively impacts their approach to decision making and identifying more appropriate strategic actions that can positively impact performance (Dragoni, Oh, Vankatwyk \& Tesluk, 2011; Wang, Holmes Jr., Oh \& Zhu, 2016). Upper echelons theory proposes a positive association with the level of CEO education and performance. Advocates of resource dependence theory (Barney, 1991) argue that a firm can gain competitive advantage to increase performance from intangible assets like human capital. To be effective as competitive advantage, the human capital should be valuable, scarce, unique with no substitutes. Barney and Arikan (2001) test the theory and conclude that firms with managers of high quality perform better than their counterparts with less quality managers. Theories suggest a positive CEO education-performance link. However, empirical works produce mixed results.

Bhagat et al. (2010) study 1,500 largest US firms in the Standard \& Poor's super-composite 1500 over 1992 to 2007. The study employs 22 education-related measures broadly belonging to two categories, field of study and ranking of the school. Both short-term, return on assets, and long-term, stock return and Tobin's Q, measures of performance are employed. The study fails to produce evidence to support CEO education-performance link and concludes that education may not be a good proxy for CEO's ability.

Gottesman and Morey (2010) test the CEO education background and performance link on a sample of 390 US firms. Educational background is defined by the type of degree and the school selection of the CEO. Performance is measured by Tobin's Q. The study finds a significant link between both the type of degree and school selectivity with Tobin's Q. Results are explained by citing the length of time that lapses between the attainment of formal education and becoming CEO. This time gap renders formal education irrelevant.

Koyuncu, Firfiray, Claes and Hamori (2010) examine the importance of the functional specialization of the CEO in operations for performance with a sample of $437 \mathrm{CEOs}$ from S\&P during 1992 to 2005. CEOs with specialization in operations are found to perform better than with finance specialization. Study attributes the increased dependence on operations specialization to enhanced focus on cost effectiveness by firms.

Jalbert et al. (2011) examine the level of education and school ranking of CEOs of large US firms during the period, 1997-2006. Performance is assessed by return on assets, return on equity and return on investment. The study shows that, while being undergraduate is essential to become CEO, a graduate degree is not. Accomplishment of undergraduate degree does not explain differences in return on assets and return on investment, but is significantly and positively related to return on investment. School rank is found to be associated with return on equity. Graduate school ranking is marginally significantly cause variations in return on assets. While undergraduate school ranking affects return on investment positively, graduate school ranking affects the variable negatively.

King et al. (2016) show that both level of education and school quality influence bank performance. A sample of 149 large US banks are studied during 1992 to 2011. Results show CEOs with an MBA have the ability to deliver better performance than their counterparts. MBA from a betterranked school is found to results in CEOs assuming more risk and adopt innovative models of business to achieve better performance. The study concludes that management degree enhances CEOs' ability to manage bigger and more complex banks and attain improved performance.

Cheng, Li and Chih (2020) evaluate if the managerial ability and firm strategy fit can influence the firm performance with a sample of 34285 firm-year observations from US listed firms during the period, 1992-2014. Along with other variables, they check if $\mathrm{CEO}$ with a management degree can impact performance. The results show a positive association with performance and a negative relationship with risk. 
In Europe, Morresi (2017) examines CEO educationperformance relation with a sample of 612 firms of market capitalization of over one billion euros listed on stock exchanges of UK, France, Italy, Spain, Germany and Netherlands during 2006 to 2015. The level of education, quality of school, and study specialization of CEO are evaluated against the accounting and market related performance. The study finds that CEOs with a higher degree and from a better-ranked school do not boost performance. But, CEOs from top ranked schools are found to enhance long-term market performance. The study infers the CEO education helps to reduce information asymmetry problem.

Ayaba (2012) analyzes the link between the level and field of education of 100 CEOs of firms listed on Stockholm stock exchange on return on assets between 2008 and 2010. Evidence produced by the study shows that both the level of education and the field of study have a limited ability to explain the performance differences. The study calls for a focus on the contemporary business challenges to be built into the curriculum offered by graduate schools.

Elsharkawy et al. (2018) investigate if the educational background of CEO of 54 UK listed banks on performance during 2005 to 2015. CEO education is defined if CEO has a business degree. Performance is measured by Tobin's Q, return on average assets, return on average equity and net interest margin. The study finds that business education has a significant positive link to Tobin's Q and net interest margin, but an insignificant positive relation to return on average assets and return on average equity.

CEO education-performance is also studied in a few developing countries as well. Darmadi (2013) studies 160 firms listed on the Indonesia stock exchange during 2007. Three measures of educational qualification of CEO and board members are correlated with two measures of firm performance. If a post graduate degree holder, if the degree is from a prestigious domestic university, if degree is from a developed country and if degree is in financial discipline are the education variables. Performance variables are return on assets and Tobin's Q. The study shows CEOs with degrees from domestic prestigious institution impact performance better than CEOs without similar qualification.

$\mathrm{Lu}$ and Zhang (2015) examine the CEO educationperformance link with the data of Chinese publicly-listed firms from 2003 to 2012. After addressing the endogeneity in the CEO education variable with the instrumental variables of the college entry exam rate in China's different provinces in different years, the impacts of cultural revolution on CEO education, and the growth environment of the CEO, the authors find that excellent CEO education can significantly enhance firm value, but cannot significantly affect firms' accounting profitability and growth rate. These findings suggest that a CEO with high education background can enhance the expectation on the value of the firm from investors; however, CEO education may not help enhance performance in the short run.

Saidu (2019) investigates CEO education-performance association with a sample of 222 firm year observations relating to financial firms listed in Nigerian stock exchange over the period, 2011-2016. Results show CEO education is positively linked to all the three measures of performance employed by the study. While the association with return on assets is statistically significant, the association with the other two variables, stock price and return on equity are not statistically significant.

Research that tests the CEO education-performance comes up with mixed results. Broadly, the empirical works employ four broad measures of CEO education, level, ranking, domestic or foreign and field of study. This study employs three of these measures namely, level, domestic or foreign and field of study. School ranking is not included as all the domestic institutions in Saudi Arabia do not have ranking by a single agency. The study proposes the following hypotheses.

Hypothesis 1: CEOs with a graduate degree perform better than CEOs with a lower qualification.

De Kort and Vermeulen (2010) suggest that CEOs with higher educational qualification may tend to become overconfident. This overconfidence may render investment and managerial decisions ineffective, harming performance. King et al. (2016) contend that both the level and quality of CEO education matter to firm performance. It is hypothesized that most of the studies in the literature are from developed country, in a developing country like Saudi Arabia where most of the firms are family businesses with boards characterized by heavy family representation, CEO with higher level of degree may positively impact performance.

Hypothesis 2: CEOS with highest educational qualification obtained from a domestic institution will perform better than CEOs with a foreign degree.

Previous works suggest lack of knowledge about domestic market may constrain the decision-making power of executives. This may diminish performance. (Lord \& Ranft, 2000) This is particularly true in case of emerging markets. (Harvey, Speier \& Novicevic, 1999) Darmadi (2013) investigates the influence of education of the CEO and the members of the board of directors on firm performance with a sample of firms from Indonesia. The evidence shows that CEOs with degree from prestigious domestic institutions enhance performance more than their counterparts without similar qualification. Saudi Arabia is an Islamic country with businesses operating in the Sharia law framework. This calls for country specific knowledge. The 
study hypothesizes a positive relationship between CEOs education from a domestic educational institution, which can have a greater emphasize on local market conditions and business environment and firm performance.

Hypothesis 3: Performance of firms with CEOs with $M B A$ degree may be higher than those without CEOs with $M B A$ degree.

The empirical literature on how effective the CEOs with an MBA degree in delivering higher performance are is mixed. Lindorff and Jonson (2013) examine the association between CEO management education on shareholder return and find no significant relationship. They conclude that management education may not offer relevant competencies at the CEO level. Degree in management enhances CEO's comprehension of sophisticated investment evaluation techniques is supporting by the findings of some empirical works (Graham \& Harvey, 2002). This may enhance performance. As the boards continue to hire CEOs with managerial qualification and compensate them more this hypothesis is tested in the context of Saudi Arabia.

\section{Data and Methodology}

All non-financial firms listed on the Saudi stock market for which data is available for the study variables for 2018 in Standard \& Poor's Capital IQ database are chosen for the study. A sample of 85 firms is chosen through this process. Data on CEO education is extracted from the annual reports of each of the company published in Saudi stock market website, www.tadawul.sa.

\subsection{Variables Studied}

This section describes the dependent and independent variables studied.

\subsubsection{Performance Variables}

Accounting measures of performance that utilize information from the financial statements are most popular in empirical works. Use of these measures is rationalized on several counts. First, data required for performance assessment can be easily ascertained from published financial statements (Richard, Devinney, Yip \& Johnson, 2009. the performance of the firm to the external stakeholders through published financial statements and hence measures based on these statements is most appropriate. In line with these suggestions from the existing literature, the study employs two measures of performance based on financial statements, namely, return on assets and return on equity.

\subsubsection{CEO Education Variables}

As mentioned in the hypothesis development section, the study includes three variables relating to CEO education that measure level of education, location of educational institution and education background. The first variable relating to the level of $\mathrm{CEO}$ education measures if the CEO has a graduate degree or above. The second variable is defined by the location of the educational institution from which the CEO obtained the highest educational qualification. On the basis of the location the institutions are classified as domestic or foreign. The third variable is about the educational background, whether the CEO has a degree in management or other branches. CEOs with a higher level of education and degree from a domestic institution are expected to enhance firm performance. If CEOs with a management degree deliver higher performance than their counterparts with a degree from other domains of expertise is hypothesized as management degree is weighs heavily in CEO hiring and compensation decisions.

\subsubsection{Control Variables}

Variables that are normally considered by the current literature are studied. These variables measure firm size, firm age, liquidity of the firm and growth. Large firms generally are more diversified, enjoy higher efficiency in operations and suffer less from information asymmetry problem (Nguyen \& Nguyen, 2020; Rajan \& Zingales, 1995; Ramaswamy, 2001; Frank \& Goyal, 2003). All these characteristics suggest enhanced performance with size. Stadler (2007) argues that firms acquire more knowledge with advancement in age. Coad, Segarra and Teruel (2013) show that productivity, profits, size and equity usage increases with age. This suggests a positive association between firm age and performance. Age may also diminish performance as matured firms may tend to resist change and are less flexible (Leonard-Barton, 1992). Liquidity may positively affect performance by meeting the firm's current obligations and facilitating its smooth function (Nguyen \& Nguyen, 2020; Nguyen, Pham \& Nguyen, 2020). Excessive liquidity may impair performance by managerial expropriation behavior of investing in negative net present value projects (Fama \& Jensen, 1983; Adams \& Buckle, 2003). Market to book ratio proxies a firm's potential to grow and is positively correlated to performance (Miller \& Modigliani, 1961; Myers, 1977; Rajan \& Zingales, 1995).

Table 1 below lists the variables included in the study and their definitions along with their expected relationship with firm performance.

Table 2 presents descriptive statistics in panel A and correlations in panel $\mathrm{B}$. ROA ranges from 5.77 percent to 
Table 1: Variables Definition

\begin{tabular}{|c|c|c|c|}
\hline Variable & Definition & Abbreviation & Expected sign \\
\hline \multirow[t]{2}{*}{ Firm performance } & Operating profit before depreciation / Total assets & ROA & \multirow{2}{*}{$\begin{array}{l}\text { Dependent } \\
\text { variables }\end{array}$} \\
\hline & Net profit / Shareholders' equity & ROE & \\
\hline \multirow[t]{3}{*}{ CEO education } & $\begin{array}{l}\text { Dummy variable equal to } 1 \text { if the CEO is a graduate } \\
\text { and } 0 \text { otherwise }\end{array}$ & D1 & + \\
\hline & $\begin{array}{l}\text { Dummy variable equal to } 1 \text { if the highest qualification of } \\
\text { the CEO is from a domestic educational institution and } \\
0 \text { otherwise }\end{array}$ & D2 & + \\
\hline & $\begin{array}{l}\text { Dummy variable equal to } 1 \text { if the highest educational } \\
\text { qualification of the CEO is in management and } 0 \\
\text { otherwise }\end{array}$ & D3 & $+/-$ \\
\hline Size & Log (Total assets) & LTA & + \\
\hline Age & Log (years since incorporation) & AGE & $+/-$ \\
\hline Liquidity & Current assets / Current liabilities & CRR & + \\
\hline Growth & $\begin{array}{l}\text { (Total assets }- \text { Book value of assets }+ \text { Market value of } \\
\text { assets) / Total assets }\end{array}$ & MTB & + \\
\hline
\end{tabular}

Table 2: Descriptive Statistics and Correlations

\begin{tabular}{|c|c|c|c|c|c|c|c|c|c|}
\hline \multicolumn{10}{|c|}{ Panel A: Descriptive Statistics } \\
\hline & ROA & ROE & D1 & D2 & D3 & LTA & AGE & CRR & MTB \\
\hline Minimum & -0.058 & -0.188 & 0 & 0 & 0 & 2.001 & 0.699 & 0.054 & 0.291 \\
\hline I quartile & 0.037 & -0.008 & 0 & 0 & 0 & 2.906 & 1.301 & 1.011 & 0.966 \\
\hline Median & 0.067 & 0.052 & 1 & 0 & 1 & 3.279 & 1.462 & 1.517 & 1.112 \\
\hline III quartile & 0.116 & 0.151 & 1 & 1 & 1 & 3.594 & 1.613 & 2.765 & 1.701 \\
\hline Maximum & 0.233 & 0.336 & 1 & 1 & 1 & 5.505 & 2.045 & 11.749 & 3.548 \\
\hline $\begin{array}{l}\text { Number of } \\
\text { observations }\end{array}$ & 85 & 81 & 85 & 85 & 85 & 85 & 85 & 81 & 85 \\
\hline \multicolumn{10}{|c|}{ Panel B: Correlations } \\
\hline ROA & 1.000 & & & & & & & & \\
\hline ROE & 0.829 & 1.000 & & & & & & & \\
\hline D1 & 0.049 & 0.124 & 1.000 & & & & & & \\
\hline D2 & 0.101 & 0.094 & -0.330 & 1.000 & & & & & \\
\hline D3 & 0.013 & 0.059 & 0.332 & -0.139 & 1.000 & & & & \\
\hline LTA & 0.513 & 0.595 & -0.033 & -0.142 & 0.161 & 1.000 & & & \\
\hline AGE & -0.053 & -0.182 & 0.008 & 0.098 & -0.238 & -0.280 & 1.000 & & \\
\hline CRR & 0.015 & -0.049 & 0.090 & -0.197 & 0.002 & -0.201 & 0.189 & 1.000 & \\
\hline MTB & 0.281 & 0.120 & -0.032 & 0.214 & -0.034 & -0.171 & 0.146 & -0.081 & 1.000 \\
\hline
\end{tabular}

23.31 percent with the median at 6.66 percent. Firms in the first quartile have a negative ROE. The median ROE is low at 5.18 per cent. Firms in the first quartile have a $\mathrm{CEO}$ who has an undergraduate degree from a foreign university, and educational qualification in a non-managerial discipline.
Firms in the higher three quartiles have a CEO with a graduate degree or higher and with a management degree. Only CEOs of firms in higher two quartiles have their highest degree from a domestic university. Looking at the base numbers, as many as 58 CEOs studied have a qualification 
of graduate degree or higher. This shows that many firms have highly educated CEOs. Only 38 CEOs have obtained their highest degrees from a domestic institution while a larger number of CEOs, 47 have graduated from a foreign university. CEOs with an MBA and with other degrees are almost equal at 44 and 41 respectively. Correlations between the study variables show that the multicollinearity may not be a problem before testing the models. The study applies ordinary least squares regression to test the following models.
$\mathrm{ROA}=f(\mathrm{D} 1, \mathrm{D} 2, \mathrm{D} 3, \mathrm{LTA}, \mathrm{AGE}, \mathrm{CRR}, \mathrm{MTB})$

$\mathrm{ROE}=f(\mathrm{D} 1, \mathrm{D} 2, \mathrm{D} 3, \mathrm{LTA}, \mathrm{AGE}, \mathrm{CRR}, \mathrm{MTB})$

\section{Results}

Regression results are reported in Table 3. Along with the OLS standard errors, as Brooks (2008) suggests the White heteroskedasticity-consistent standard errors is also reported to handle the problem of heteroskedasticity. The

Table 3: Regression results

\begin{tabular}{|c|c|c|c|c|c|c|c|}
\hline \multicolumn{8}{|c|}{ Model 1} \\
\hline Variable & Coefficient & OLS -SE & t-statistic & Prob. & White-SE & t-statistic & Prob. \\
\hline Constant & -0.1502 & 0.0528 & $-2.8430^{* * *}$ & 0.0058 & 0.0486 & $-3.0895^{* * *}$ & 0.0028 \\
\hline D1 & 0.0287 & 0.0133 & $2.1584^{* *}$ & 0.0342 & 0.0130 & $2.2088^{* *}$ & 0.0303 \\
\hline D2 & 0.0293 & 0.0122 & $2.3943^{\star *}$ & 0.0192 & 0.0119 & $2.4661^{\text {** }}$ & 0.0160 \\
\hline D3 & -0.0179 & 0.0120 & -1.4893 & 0.1407 & 0.0122 & -1.4674 & 0.1466 \\
\hline LTA & 0.0577 & 0.0086 & $6.6873^{* * *}$ & 0.0000 & 0.0090 & $6.4466^{\star * *}$ & 0.0000 \\
\hline AGE & -0.0204 & 0.0246 & -0.8288 & 0.4099 & 0.0195 & -1.0478 & 0.2982 \\
\hline CRR & 0.0060 & 0.0029 & $2.1074^{* *}$ & 0.0385 & 0.0019 & $3.1377^{* * *}$ & 0.0025 \\
\hline MTB & 0.0389 & 0.0091 & $4.2985^{\star * *}$ & 0.0001 & 0.0122 & $3.2025^{\star * *}$ & 0.0020 \\
\hline $\begin{array}{l}\text { Adjusted } \\
\text { R-squared }\end{array}$ & 0.4085 & & & & & & \\
\hline F-statistic & $8.8916^{* * *}$ & & & & & & \\
\hline $\begin{array}{l}\text { Prob(F- } \\
\text { statistic) }\end{array}$ & 0.0000 & & & & & & \\
\hline \multicolumn{8}{|c|}{ Model 2} \\
\hline Constant & -0.3231 & 0.0978 & $-3.3034^{* * *}$ & 0.0015 & 0.0730 & $-4.4283^{* * *}$ & 0.0000 \\
\hline D1 & 0.0667 & 0.0238 & $2.8022^{* * *}$ & 0.0066 & 0.0239 & $2.7924^{\star * *}$ & 0.0068 \\
\hline D2 & 0.0610 & 0.0223 & $2.7384^{* * *}$ & 0.0078 & 0.0232 & $2.6314^{* * *}$ & 0.0105 \\
\hline D3 & -0.0288 & 0.0218 & -1.3204 & 0.1911 & 0.0203 & -1.4219 & 0.1596 \\
\hline LTA & 0.1180 & 0.0156 & $7.5729^{\star * *}$ & 0.0000 & 0.0156 & $7.5842^{* * \star}$ & 0.0000 \\
\hline AGE & -0.0510 & 0.0449 & -1.1355 & 0.2601 & 0.0355 & -1.4344 & 0.1560 \\
\hline CRR & 0.0087 & 0.0051 & $1.7201^{*}$ & 0.0899 & 0.0034 & $2.5728^{* * *}$ & 0.0122 \\
\hline MTB & 0.0405 & 0.0166 & $2.4453^{* *}$ & 0.0170 & 0.0174 & $2.3335^{\star *}$ & 0.0225 \\
\hline $\begin{array}{l}\text { Adjusted } \\
\text { R-squared }\end{array}$ & 0.4538 & & & & & & \\
\hline F-statistic & $10.0216^{* * *}$ & & & & & & \\
\hline $\begin{array}{l}\text { Prob(F- } \\
\text { statistic) }\end{array}$ & 0.0000 & & & & & & \\
\hline
\end{tabular}

Model 1 dependent variable: ROA; Model 2 dependent variable: ROE;

OLS-SE refers to OLS standard errors considering homoscedasticity

White-SE refers to White standard errors considering heteroscedasticity

*** Significant at $1 \%$ level; ** Significant at $5 \%$ level; * Significant at $10 \%$ level 
results of the regressions run are consistent across both the measures of firm performance. We find CEOs with higher level of qualification and the highest degree from a domestic educational institution enhance firm performance, while performance of CEOs with a management degree is not found to be statistically significant. Larger firms, firms with higher liquidity and higher growth rate are found to be more profitable. Younger firms are found to perform better than older firms. Our results are in line with the proposed hypotheses.

Jarque-Bera (1980) test is for checking if the residuals are normal. We find the residuals of both the models are normally distributed. The models tested do not suffer from misspecification error and multicollinearity problem as evident from the Ramsey regression equation specification error test and variance inflation factor reported. All the results of the diagnostic tests show that the results of the models are dependable (see Table 4).

Our results that CEOs with a higher educational qualification and CEOs who graduate from a domestic institution perform better than their counterparts are in line with the results of some of the previous works (Darmadi, 2013; King et al., 2016). That a management degree may not help a CEO to deliver a higher performance is also supported by the findings of earlier studies (Lindorff \& Jonson, 2013). Finkelstein, Hambrick and Cannella (2009) attribute to the fact that executives arrive at the top after many years of completion of formal education.

\section{Discussion and Conclusion}

Human capital theory relates CEO education to higher earnings thorough increased marginal productivity of labor.
Upper echelons theory postulates that CEO education relates to firm performance as it can impact strategic choices. Resource dependence theory contemplates a positive link between CEO education and firm performance as CEOs with a higher qualification may prove to be a source of competitive advantage. Results of this study show a positive CEO education-performance link. The findings are consistent with the contentions of all these theories. It may be inferred that CEOs with a higher educational qualification have a better ability to handle complex business organizations, adopt effective profitable strategies and prove to be a valuable human resource to the firm as suggested by the theories.

Saudi Arabia is an Islamic country following sharia law and has a typical business environment of an oil-dependent economy. All these call for knowledge about the business, cultural, legal and economic conditions unique to the country. This may be the reason why CEOs with the highest degree from a domestic university deliver superior performance compared to CEOs with their qualification from a foreign university. Firms in Saudi Arabia have a critical role to play in fructifying the Vision 2030 of the country in diversifying the economy from oil by promoting investments in new sectors like mining, recreation and tourism. Such an emphasis that provides the direction for future economic growth may hold the key to explaining why CEOs with the higher educational degree and from a domestic institution perform better. Besides, this may also call for CEOs with technical and operational knowledge specific to these sectors may be the need of the hour rather than a management degree.

Our findings have important implications for firms in Saudi Arabia. Like all other GCC countries, Saudi Arabia is dominated by family firms. In the Gulf region, family firms play a prominent role in their economic contribution. They

Table 4: Results of Diagnostic Tests

\begin{tabular}{|c|c|c|}
\hline & Model 1 & Model 2 \\
\hline $\begin{array}{l}\text { Jarque-Bera test for normality of } \\
\text { residuals }\end{array}$ & $\begin{array}{c}0.6617 \\
(0.7183)\end{array}$ & $\begin{array}{c}0.2537 \\
(0.8809)\end{array}$ \\
\hline \multirow[t]{2}{*}{$\begin{array}{l}\text { Ramsey regression equation } \\
\text { specification error test (RESET) }\end{array}$} & $\begin{array}{c}0.32 \\
(0.8126) \\
\end{array}$ & $\begin{array}{c}0.53 \\
(0.6661) \\
\end{array}$ \\
\hline & Variance inflation factor & Variance inflation factor \\
\hline D1 & 1.25 & 1.28 \\
\hline D2 & 1.22 & 1.26 \\
\hline D3 & 1.19 & 1.22 \\
\hline LTA & 1.18 & 1.19 \\
\hline AGE & 1.15 & 1.19 \\
\hline CRR & 1.13 & 1.14 \\
\hline MTB & 1.07 & 1.09 \\
\hline
\end{tabular}

$P$ value in parenthesis 
contribute around 60 percent to GDP, hire around 80 percent of the labor force with an estimated stake of around one trillion USD to be passed to the generation next (PwC family business survey, 2019). A large number of these family businesses already have members of the family in the top management positions and preparing successors to take over the leadership of their businesses. KPMG's family business survey of 2017 shows that around 60 percent of the family businesses surveyed were led by family and 88 percent of the firms are preparing to find successors for leadership from the family (home.kpmg/sa.html). Our findings that firms with CEOs with a higher degree and from a domestic university perform better than their counterparts should be considered in the succession plans of the family firms.

Due to the tedious data collection process the current study is based on a single year, however, an analysis for a longer period may confirm the generalization of the results of this study. The study points out the need for further research on how CEO education impacts the performance of family versus non-family firms.

\section{References}

Adams, M., \& Buckle, M. (2003). The determinants of corporate financial performance in Bermuda insurance market. Applied Financial Economics, 13(2), 133-143. doi:10.1080/09603100210105030

Adams, R., Almeida, H., \& Ferreira, D. (2005). Powerful CEOs and their impact on corporate performance. Review of Financial Studies, 18(4), 1403-1432. doi:10.1093/rfs/hhi030

Ayaba, O.H. (2012). Chief Executive Officer's (CEO's) educational background and performance: an empirical study on manufacturing and IT listed firms in the Stockholm stock exchange. Sweden: Master thesis, Umea School of Business and Economics.

Barney, J., \& Arikan, A.M. (2011). The resource-based view: origins and implications. In M.A. Hitt, R.E. Freeman and J.S. Harrison (Eds.) The Blackwell Handbook of Strategic Management (pp.124-186), Oxford, UK: Blackwell.

Barney, J. (1991). Firm resources and sustained competitive advantage. Journal of Management, 17(1), 99-120. doi:10.117 7\%2F014920639101700108

Becker, G.S. (1964). Human capital. New York, NY: Columbia University Press.

Bertrand, M., \& Scholar,A.(2003). Managing with style: The effect of managers on firm policies. The Quarterly Journal of Economics, 118(4), 1169-1208. doi:10.1162/003355303322552775

Bhagat, S., Bolton, B., \& Subramanian, A. (2010). CEO education, CEO turnover, and firm performance. https://papers.ssrn.com/ sol3/papers.cfm?abstract_id=1670219

Bowers, D. G., \& Seashore, S. E. (1966). Predicting organizational effectiveness with a four-factor theory of leadership. Administrative Science Quarterly, 11(2), 238-263. doi: $10.2307 / 2391247$

Brooks, C. (2008). Introductory Econometrics for Finance ( $2^{\text {nd }}$ ed.). Cambridge: Cambridge University Press.

Certo, S. T. (2003). Influencing initial public offering investors with prestige: signaling with board structures. The Academy of Management Journal, 28(3), 432-446 doi:10.5465/ amr.2003.10196754

Cheng, T.Y., Li, Y., Lin, Y., \& Chinh, H. (2020). Does the fit of managerial ability with firm strategy matters on firm performance. Journal of Asian Finance, Economics and Business, 7(4), 9-19. https://doi.org/10.13106/jafeb.2020.vol7. no4.9

Coad, A., Segarra, A., \& Teruel, M. (2013). Like milk or wine: does firm performance improve with age? Structural Change and Economic Dynamics, 24(3), 173-189. doi:10.1016/j. strueco.2012.07.002

Colbert, A.E., Barrick, M.R., \& Bradley, B.H. (2014). Personality and leadership composition in top management teams: implications for organizational effectiveness. Personnel Psychology, 67(2), 351-387. doi:10.1111/peps.12036

Danielson, M. G., \& Press, E. (2003). Accounting returns revisited: evidence of their usefulness in estimating economic returns. Review of Accounting Studies, 8(4), 493-530. doi:10.1023/A:1027368116754

Darmadi, S. (2013). Board members' education and firm performance: evidence from a developing economy. International Journal of Commerce and Management, 23(2), 113-135 doi:10.1108/10569211311324911.

De Kort, M.J.J., \& Vermeulen, P.A.M. (2010). Entrepreneurial decision-makers and the use of biases and heuristics. In P.A.M. Vermeulen and P.L. Cursue (Eds.) Entrepreneurial strategic decision-making: a cognitive perspective. (pp.123-134). Cheltenham: Edward Elgar Publishing Limited.

Dragoni, L., Oh, I-S, Vankatwyk, P., \& Tesluk, P.E. (2011). Developing executive leaders: the relative contribution of cognitive ability, personality, and the accumulation of work experience in predicting strategic thinking competency. Personnel Psychology, 64(4), 829-864. doi:10.1111/j.17446570.2011.01229.x

Elsharkawy, M., Paterson, A.S., \& Sherif, M. (2018). Now you see me: diversity, CEO education, and bank performance in the UK. Investment Management and Financial Innovations, 15(1), 277-291. doi:10.21511/imfi.15(1).2018.23

Falato, A., Li, D., \& Milbourn, T. (2015). Which skills matter in the market for CEOs? Evidence from pay for CEO credentials. Management Science, 61(12), 2845-2869. doi:10.1287/ mnsc.2014.2024

Fama, E.F., \& Jensen, M.C. (1983). Agency problems and residual claims. Journal of Law and Economics, 26(2), 327-349. doi:10.1086/467038 
Finkelstein, S., Hambrick, D., \& Cannella, A.A. (2009). Strategic leadership: theory and research on executives, top management teams and boards. New York: Oxford University Press.

Frank, M., \& Goyal, V.K. (2003). Testing the pecking order theory of capital structure. Journal of Financial Economics, 67(2), 217-248. doi:10.1016/S0304-405X(02)00252-0

Gottesman, A.A., \& Morey, M.R. (2010). CEO educational background and firm financial performance. Journal of Applied Finance, 20(2), 1-13. Retrieved from https://papers.ssrn.com/ sol3/papers.cfm?abstract_id=2693079

Gottfredson, L.S. (2003). The challenge and promise of cognitive career assessment. Journal of Career Assessment, 11(2), 115135. doi:10.1177\%2F1069072703011002001

Graham, J., \& Harvey, C. (2002). How do CFOs make capital budgeting and capital structure decisions? Journal of Applied Corporate Finance, 15(1), 8-23. doi:10.1111/j.1745-6622.2002. tb00337.x

Graham, J.R., Harvey, C.R., \& Puri, M. (2013). Managerial attitudes and corporate actions. Journal of Financial Economics, 109(1), 103-121. doi:10.1016/j.jfineco.2013.01.010

Graham, J.R., Li, S., \& Qiu, J. (2012). Managerial attributes and executive compensation. The Review of Financial Studies, 25(1), 144-186. doi:10.1093/rfs/hhr076

Hambrick, D.C., \& Mason, P.A. (1984). Upper echelons: the organization as a reflection of its top managers. Academy of Management Review, 9(2), 193-206. doi:10.5465/ amr.1984.4277628

Harvey, M.G., Speier, C., \& Novicevic, M.M. (1999). The impact of emerging markets on staffing the global organization: a knowledge-based view. Journal of International Management, 5(3), 167-186.

Hiller, N.J., \& Hambrick, D.C. (2005). Conceptualizing executive hubris: The role of (hyper-) core self-evaluations in strategic decision-making. Strategic Management Journal, 26(4), 297319. doi:10.1002/smj.455

Hunter, J.E. (1986). Cognitive ability, cognitive aptitudes, job knowledge, and job performance. Journal of Vocational Behavior, 29(3), 340-362. doi:10.1016/0001-8791(86)90013-8

Jalbert, T., Furumo, K., \& Jalbert, M. (2011). Does educational background affect CEO compensation and firm performance? Journal of Applied Business Research, 27(1), 15-39. doi:10.19030/jabr.v27i1.907

Jarque, C.M., \& Bera, A.K. (1980). Efficient tests for normality, homoscedasticity and serial independence of regression residuals. Economics Letters, 6(3), 255-259. doi:10.1016/01651765(80)90024-5

Kaplan, S.N., Klebanov, M.M., \& Sorensen, M. (2012). Which CEO characteristics and abilities matter? The Journal of Finance, 67(3), 973-1007. doi:10.1111/j.1540-6261.2012.01739.x

King, T., Srivastav, A., \& Williams, J. (2016). What's in an education? Implications of CEO education for bank performance. Journal of Corporate Finance, 37, 287-308. doi:10.1016/j.jcorpfin.2016.01.003

Koyuncu, B., Firfiray, S., Claes, B., \& Hamori, M. (2010). CEOs with a functional background in operations: reviewing their performance and prevalence in the top post. Human Resource Management, 49 (5), 869-882. doi:10.1002/hrm.20389

KPMG (2018). GCC family business survey 2017: driving the region forward. Retrieved May 20, 2020 from https://assets. $\mathrm{kpmg} /$ content/dam/kpmg/ae/pdf/family-business.pdf

Leonard-Barton, D. (1992). Core capabilities and core rigidities: a paradox in managing new product development. Strategic Management Journal, 13(1), 111-125. doi:10.1002/ smj.4250131009

Lindorff, M., \& Jonson, P.E. (2013). CEO business education and firm financial performance: a case for humility rather than hubris. Education + Training, 55(4/5), 461-477. doi:10.1108/00400911311326072

Lord, M.D., \& Ranft, A.L. (2000). Organizational learning about new international markets: exploring the internal transfer of local market knowledge. Journal of International Business Studies, 31(4), 573-589. doi:10.1057/palgrave.jibs.8490923

Lu, Y., \& Zhang, M. (2015). Effects of CEO education background on firm performance. Journal of Tsinghua University (Science and Technology), 4(10), 428-442.

Malmendier, U., Tate, G., \& Yan, J. (2011). Overconfidence and early-life experiences: the effect of managerial traits on corporate financial policies. The Journal of Finance, 66(5), 1687-1733. doi:10.1111/j.1540-6261.2011.01685.x

Miller, M., and Modigliani, F. (1961). Dividend policy, growth and the valuation of shares. Journal of Business, 34(4), 411-433. doi: $10.1086 / 294442$

Mincer, J. (1958). Investment in human capital and personal income distribution. The Journal of Political Economy, 66(4), 281-302.

Morresi, O. (2017). How much is CEO education worth to a firm? Evidence from European firms. PSL Quarterly Review, 70(282), 311-353. doi:10.13133/2037-3643_70.282_4

Myers, S.C. (1977). Determinants of corporate borrowing. Journal of Financial Economics, 5(2), 147-175. doi:10.1016/0304405X(77)90015-0

Ng, T.W.H., \& Feldman, D.C. (2009). Age, work experience, and the psychological contract. Journal of Organizational Behavior, 30(8), 1053-1075. doi:10.1002/job.599

Nguyen, T.N.L., \& Nguyen, V.C. (2020). The determinants of profitability in listed enterprises: a study from Vietnamese stock exchange. Journal of Asian Finance, Economics and Business, 7(1), 47-58. https://doi.org/10.13106/jafeb.2020.vol7.no1.47

Nguyen, A.H., Pham, H.T., \& Nguyen, H.T. (2020). Impact of working capital management on firm's profitability: empirical evidence from Vietnam. Journal of Asian Finance, Economics and Business, 7(3), 115-125. https://doi.org/10.13106/ jafeb.2020.vol7.no3.115 
PwC (2019). PwC middle east family business survey, 2019. Retrieved May 20, 2020 from https:/www.pwc.com/m1/en/ publications/documents/family-business-survey-2019.pdf

Rajan, R.G., \& Zingales, L. (1995). What do we know about capital structure decisions? Some evidence from international data. The Journal of Finance, 50(5), 142-160. doi:10.1111/j.1540-6261.1995.tb05184.x

Ramaswamy, K. (2001). Organizational ownership, competitive intensity and firm performance: an empirical study of Indian manufacturing sectors. Strategic Management Journal, 22(10), 989-998. doi:10.1002/smj.204

Richard, P.J., Devinney, T. M., Yip, G. S., \& Johnson, G. (2009). Measuring organizational performance: towards methodological best practice. Journal of Management, 35(3), 718-804. doi:10.1177\%2F0149206308330560

Robinson, P. B., \& Sexton, E. A. (1994). The effect of education and experience on self-employment success. Journal of Business Venturing, 9(2), 141-159. doi:10.1016/0883-9026(94)90006-X
Saidu, S. (2019). CEO characteristics and firm performance: focus on origin, education and ownership. Journal of Global Entrepreneurship Research, 9(29), doi:10.1186/s40497-0190153-7

Thomas, A.S., Litschert, R.J., \& Ramaswamy, K. (1991). The performance impact of strategy-manager coalignment: An empirical examination. Strategic Management Journal, 12(7), 509-522. doi:10.1002/smj.4250120704

Wally, S., \& Baum, J.R. (1994). Personal and structural determinants of the pace of strategic decision making. The Academy of Management Journal, 37(4), 932-956. doi:10.2307/256605

Wang, G., Holmes Jr., R.M., Oh, I-S., \& Zhu, W. (2016). Do CEOs matter to firm strategic actions and firm performance? A meta-analytic investigation based on upper echelons theory. Personnel Psychology, 69(4), 775-862. doi:10.1111/peps.12140

Xiaowei, V.K., \& Zhang, J. (2010). The effect of managerial education and firm-ownership structure: empirical evidence from Chinese listed firms. The Chinese Economy, 43(6), 34-53. doi:10.2753/1097-1475430604 